\title{
Milk protein for improved metabolic health: a review of the evidence
}

\author{
Robin A McGregor ${ }^{1,2^{*}}$ and Sally D Poppitt ${ }^{1,2,3,4}$
}

\begin{abstract}
Epidemiological evidence shows that consumption of dairy products is associated with decreased prevalence of metabolic related disorders, whilst evidence from experimental studies points towards dairy protein as a dietary component which may aid prevention of type 2 diabetes (T2DM). Poor metabolic health is a common characteristic of overweight, obesity and aging, and is the forerunner of T2DM and cardiovascular disease (CVD), and an ever increasing global health issue. Progressive loss of metabolic control is evident from a blunting of carbohydrate, fat and protein metabolism, which is commonly manifested through decreased insulin sensitivity, inadequate glucose and lipid control, accompanied by a pro-inflammatory environment and hypertension. Adverse physiological changes such as excess visceral adipose tissue deposition and expansion, lipid overspill and infiltration into liver, muscle and other organs, and sarcopaenia or degenerative loss of skeletal muscle mass and function all underpin this adverse profile. 'Sarcobesity' and sarcopaenic diabetes are rapidly growing health issues. As well as through direct mechanisms, dairy protein may indirectly improve metabolic health by aiding loss of body weight and fat mass through enhanced satiety, whilst promoting skeletal muscle growth and function through anabolic effects of dairy protein-derived branch chain amino acids (BCAAs). BCAAs enhance muscle protein synthesis, lean body mass and skeletal muscle metabolic function. The composition and processing of dairy protein has an impact on digestion, absorption, BCAA kinetics and function, hence the optimisation of dairy protein composition through selection and combination of specific protein components in milk may provide a way to maximize benefits for metabolic health.
\end{abstract}

Keywords: Dairy protein, Milk, Whey protein, Metabolic health, Hyperglycaemia, Dyslipidaemia, Blood pressure, Inflammation, Body weight

\section{Introduction}

Poor metabolic health represents an ever increasing global epidemic based on estimates from countries as far ranging as the US and China $[1,2]$. Encompassed within metabolic health are the cluster of interrelated adverse metabolic markers of hyperglycaemia, dyslipidaemia and hypertension which alongside central or abdominal obesity have been termed the metabolic syndrome $[3,4]$. Individuals with metabolic syndrome are at twice the risk of developing cardiovascular disease (CVD) within 5-10 years, in addition to a 5-fold increase in risk of

\footnotetext{
* Correspondence: r.mcgregor@auckland.ac.nz

${ }^{1}$ School of Biological Sciences, University of Auckland, Auckland 1010, New

Zealand

${ }^{2}$ University of Auckland Human Nutrition Unit, 18 Carrick Place, Mt Eden,

Auckland 1024, New Zealand

Full list of author information is available at the end of the article
}

developing T2DM [3], and therefore maintenance of good metabolic health is critically important.

A continuum of metabolic health exists from young, lean, healthy individuals with good physiological control to those with impaired metabolic regulation who are commonly overweight or obese, as well as older. Progressive loss of metabolic control is characterized by a range of physiological changes which include excess adipose deposition, lipid overspill, infiltration and accumulation in key organs such as liver and skeletal muscle, alongside blunting of carbohydrate $(\mathrm{CHO})$, fat and protein metabolism, decreased insulin sensitivity and hyperglycaemia, dyslipidaemia, increased inflammation, impaired endothelial function [5], and blunted muscle protein synthesis and decreased muscle mass, structure and function [6]. Multiple factors may contribute to the progressive loss of metabolic control, but obesity, ageing and physical inactivity are

\section{() Biomed Central}


recognized as major drivers of these changes in metabolic health $[3,4]$.

Obesity is of particular importance and a prolonged positive energy balance with subsequent lipid deposition and expansion of adipose depots [7], particularly visceral depots which secrete inflammatory cytokines, play a role in insulin resistance and decreased insulin-mediated glucose uptake [8]. Lipid turnover is decreased and mitochondrial oxidation is suppressed in obese subjects, promoting intracellular accumulation of lipids and the buildup of deleterious lipid metabolites in multiple tissues including skeletal muscle, liver, pancreatic beta cells, kidney and hypothalamus amongst others [9]. Subsequently, infiltration of inflammatory cells to clear toxic metabolic byproducts is accompanied by release of inflammatory cytokines that inhibit metabolic signaling pathways [10], as well as promote cell death, tissue fibrosis and functional impairment. The recommended treatment to improve metabolic health includes changes in diet and physical activity, which promote adipose tissue loss, enhance metabolically active skeletal muscle mass and hence improve metabolic control [5]. Energy restricted diets are widely recommended for weight-loss in overweight or obese individuals with poor metabolic health, however $\sim 25 \%$ of body weight loss can be attributable to decreases in skeletal muscle mass [11-13]. Loss of skeletal muscle is undesirable because it is essential for mobility and activities of daily living. In addition, skeletal muscle also plays a major role in glycaemic control accounting for up to $75 \%$ of tissue glucose uptake. Mitochondrial oxidative capacity is decreased in obese skeletal muscle, as well as in T2DM, possibly due to underlying physical inactivity [14].

Advancing age and a sedentary lifestyle are also risk factors for a gradual loss of skeletal muscle mass, function and in turn muscle strength. The problem is commonly compounded by increased adipose tissue accumulation and myocellular lipid infiltration which provides the basis of sarcopenic (accelerated muscle loss) obesity, and which in turn may drive insulin resistance and increase metabolic risk [15]. Intramyocellular lipid accumulation in obese individuals appears to be difficult to reverse through weightloss interventions [16]. Activation of skeletal muscle protein anabolism appears to be blunted in both the obese [17] and the elderly, although again this may be attributable to a common underlying physical inactivity and insulin resistance $[6,18]$. If metabolic health does not improve with diet or exercise interventions, pharmacological agents can be resorted to in order to manage dyslipidaemia, hypertension and hyperglycemia and loss of metabolic homeostasis.

Currently, there is considerable interest in the use of dairy proteins as supplements or in conjunction with lifestyle changes to improve metabolic health [19-23]. Evidence from some epidemiological studies suggest that greater consumption of dairy products is associated with lower risk of metabolic related disorders and CVD $[20,24]$. Multiple dairy components in milk such as whey protein, casein and minerals have been posited as drivers of these beneficial effects [20], and there is a growing body of intervention studies assessing the effects of cow's milkderived proteins [23] or peptides on metabolic health [25]. The focus of many of these interventions has been the whey component of milk, which may act to improve cardiometabolic risk factors. Whey protein has been shown to be an insulin secretagogue [26], as well as to improve body weight and adiposity through increased satiety [19]. In addition to a dietary strategy to promote adipose loss, dairy proteins have also been shown to increase skeletal muscle mass through stimulation of muscle protein synthesis [27]. Peptides derived from dairy protein have also been widely investigated as potential inhibitors of angiotensin-converting enzyme (ACE), thereby regulating blood pressure [28], and may influence activation of the innate immune system and inflammation [29].

\section{Milk processing, protein composition and kinetics}

Dairy protein consumed by humans is predominantly from cow's milk, which consists of around $80 \%$ (w/w) casein, $20 \%(\mathrm{w} / \mathrm{w})$ whey proteins and is also a rich source of minerals such as calcium. The casein in cow's milk comprises alpha-s1, alpha-s2, beta and kappa-casein, whilst whey comprises multiple globular proteins including betalactoglobulin, alpha-lactalbumin, lactoferrin, immunoglobulins, serum albumin, glycomacropeptide, enzymes and growth factors. All of these components have potential to contribute to the observed association between increased consumption of dairy products and decreased risk of metabolic disease observed in several epidemiological studies $[20,30,31]$.

\section{Cow's milk processing}

Cow's milk processing is an important factor determining the composition, concentration and physiological effects of whey protein or casein [32,33]. Milk is commonly separated into different protein fractions for different food applications [34]. Milk protein concentrate (MPC), produced by ultrafiltration of skimmed milk, contains both casein and whey proteins in similar proportions to whole milk, but the total amount of protein, lactose and mineral content may vary between different MPC formulations. Micellar casein can be extracted from milk protein concentrate by further ultrafiltration. Casein is produced from skim milk by acid precipitation or enzymatic coagulation, washing and drying. Caseinates are produced by treatment of acidified or coagulated casein curd with alkali such as sodium hydroxide or calcium hydroxide, which forms sodium or calcium caseinates respectively; caseinates contain $\sim 90 \%$ protein. Whey protein 
concentrate is produced by coagulation of milk with the enzyme rennet or acid, resulting in separation of curds and whey, further ultrafiltration and drying produces whey protein concentrates containing $\sim 25-80 \%$ protein. Additional processing can produce whey protein isolates containing $>90 \%$ protein with very low amounts of lactose and lipids. Hydrolysis with enzymes or acids provides a way to breakdown the structure of whey or casein. In metabolic-related studies a range of processed milk proteins have been used including milk protein concentrate, micellar casein, casein, sodium caseinate, calcium caseinate, casein hydrolysate, whey protein concentrate, whey protein isolate and whey protein hydrolysate, as well as a range of whey and casein peptides.

\section{Amino acid profile of milk proteins}

Whey protein and casein are both classified as high quality proteins based on human amino acid (AA) requirements, digestibility and their bioavailability. They contain a relatively high proportion of indispensible AAs, score higher than most other protein sources across a wide range of assessment methods including the protein digestibility corrected AA score (PDCAAS) [35] and recently developed digestible indispensable amino acid score (DIAAS) method [36]. Nevertheless, differences in the physiological effects of whey protein and casein have been attributed to differences in their AA composition [37]. Whey protein contains a higher proportion of the branched chain amino acids (BCAA) leucine, isoleucine and valine compared to casein [38]. The BCAAs alone and in particular leucine have been shown to trigger a potent increase in protein synthesis in T2DM [39]. Among the other indispensible or essential amino acids (EAAs), casein contains a higher proportion of histidine, methionine, phenylalanine and valine than whey protein [38]. In addition, casein also contains a higher proportion of several non-EAAs including arginine, glutamic acid, proline, serine and tyrosine [38].

\section{Gastric emptying, absorption and serum kinetics of milk proteins}

Whey protein is reported to be absorbed faster than casein [40]. The lower absorption rate of casein in its native micellar form is because the low $\mathrm{pH}$ conditions in the stomach cause casein to clot and delays gastric emptying [41]. Therefore, plasma AAs are more rapidly elevated following whey protein consumption, whereas changes in plasma AAs are lower and more sustained following micellar casein consumption [40]. Processing of whey protein or casein fractions via hydrolysis can markedly influence absorption and subsequent plasma AA profiles. A casein hydrolysate is reported to be absorbed more rapidly than intact micellar casein, resulting in a greater increase in plasma AAs [42]. Conversely, whey protein hydrolysate intake is reported to result in similar plasma AA levels compared to whey protein concentrate [43], because of similar rapid rates of gastric emptying and absorption. The processing of micellar casein by acidification and then neutralization with alkali such as sodium hydroxide or calcium hydroxide to form caseinates also markedly alters plasma AA profiles compared to micellar casein [44].

\section{Milk proteins, insulin secretion and glucose control Insulinotropic effects}

Insulin is sensitive to both the composition and concentration of plasma AAs, hence both whey and casein ingestion stimulate increased insulin secretion [45,46]. Ingestion of whey protein leads to more rapid secretion of insulin than micellar casein [40], however, hydrolysis of casein speeds up the absorption of AAs and secretion of insulin relative to the micellar form of casein [42]. Insulin has wide-ranging direct and indirect effects on $\mathrm{CHO}$, fat and protein metabolism, including stimulation of glucose uptake, glycogen synthesis, lipid uptake, triglyceride (TG) synthesis, protein synthesis and inhibition of protein breakdown, lipolysis and gluconeogenesis. Therefore, the stimulation of insulin secretion by different milk proteins may make a significant contribution to metabolic effects in insulin sensitive tissues and in particular skeletal muscle anabolism. Prolonged, elevated fasting glucose is a key metabolic risk factor, one of the main characteristics of T2DM and associated with an increased risk of CVD [47]. Hyperglycaemia develops with increased insulin resistance and failure of insulin secretion.

\section{Postprandial glycaemia}

Management of non-fasting or postprandial glucose response is important to minimize prolonged exposure to high blood glucose levels in individuals both with and without T2DM [48]. Plasma glucose can increase protein glycosylation, nonenzymatic glycation products and the generation of free radicals, as well as decrease nitric oxide production leading to damage to the macro- and microvasculature [48]. Of significant importance to dairy are the milk proteins whey and casein which stimulate insulin release, and have the potential to alter tissue glucose uptake and suppress postprandial blood glucose excursions [43,45,46,49-51].

Many of the studies on the insulinotropic inducing properties of whey protein or casein have been conducted in healthy men rather than individuals with impaired glucose control $[43,45,46,49-51]$. The AA profile of whey protein is suggested to contribute to its insulinotropic effects, however, the protein format has been shown to have variable effects on insulin secretion. AA-supplemented drinks containing several insulinotropic AAs found at high levels in whey protein (e.g. leucine, isoleucine, valine, 
lysine, threonine) are reported to result in similar insulinaemic and glycaemic responses [46]. A recent study showed co-ingestion of these AAs with $9 \mathrm{~g}$ whey protein however did not further augment the suppression of postprandial glucose after a $\mathrm{CHO}$ meal [52], which may be due to a ceiling in the stimulation of insulin by free AAs and AAs derived from intact protein. One study has shown that insulinotropic effects between intact whey protein and whey protein hydrolysate does not vary in healthy individuals at doses of 20-50 g protein [43]. Conversely, in a different study whey protein concentrate but not hydrolysate decreased postprandial blood glucose and insulin responses in a dose dependent manner (10-40 g) following an ad libitum mixed meal, although the authors noted that this was most likely because food intake was decreased at this free choice meal [49], hence confounding these effects.

In individuals with T2DM, $18 \mathrm{~g}$ whey protein added to breakfast or lunch resulted in greater insulinotropic responses, circulating levels of the gut peptide glucosedependent insulinotropic polypeptide (GIP), and suppression of postprandial glycaemia than following an isoenergetic non-dairy protein (lean ham and lactose) [53]. $55 \mathrm{~g}$ whey protein ingested before or with a $\mathrm{CHO}$ lunch also suppressed postprandial glucose in T2DM patients [54], triggering greater insulinotropic, and gut peptide (GIP and cholecystokinin, CCK) responses [54]. Gastric emptying was only inhibited with pre-meal whey protein ingestion, although there was no evidence that this was any more effective for postprandial glycaemic control than ingestion with a meal [54]. It is of considerable interest that the acute effects of whey protein on postprandial blood glucose are comparable to sulfonylureas and other insulin secretagogues used for the pharmaceutical management of hyperglycaemia in T2DM. Sulfonylureas stimulate increased secretion of (pro) insulin by binding to ATP-dependent potassium channels in pancreatic $\beta$-cells [55]. Therefore, there is a rationale for regular whey protein ingestion before or with meals to manage postprandial glycaemic responses in individuals with poor metabolic control or T2DM.

Effects of casein may be less consistent. In an overweight group with T2DM, consumption of a casein hydrolysate $(\sim 30 \mathrm{~g})$ and leucine $(\sim 10 \mathrm{~g})$ beverage after breakfast, lunch and dinner decreased prevalence of hyperglycaemia over the course of 24 hours [56]. Yet in another study of patients with long-standing T2DM, higher $40 \mathrm{~g}$ dose casein hydrolysate given at each main meal did not improve the prevalence of hyperglycemia over 24 hours [57], possibly attributable to $\beta$-cell impairment characteristic of long-term T2DM. Although, even in long-standing T2DM however, there is some evidence that the insulin secretory mechanism is retained and can be re-activated by ingestion of free $\mathrm{AA}$ and protein mixtures including free leucine, free phenylalanine and wheat protein hydrolysate [58]. Possibly whey protein or casein could improve hyperglycemia over 24 hours in individuals with metabolic syndrome or early T2DM characterized by insulin resistance but still functional $\beta$-cells.

\section{Chronic fasting glycaemia}

To date there have been few randomized controlled trials of longer-term whey protein or casein supplementation on glycaemic control. In the only study of which we are aware in overweight and obese individuals, 12 weeks of $54 \mathrm{~g} /$ day whey protein isolate or sodium caseinate supplementation without any lifestyle intervention resulted in a decrease in fasting blood insulin levels and insulin resistance, but not fasting blood glucose levels [59], compared to 12 weeks of glucose supplementation. Most individuals at the start of the trial had borderline impaired glucose tolerance (IGT) as well as other metabolic risk factors including high TG, low HDL-C and high waist circumference [59]. Further long-term trials of whey protein or casein in individuals with IGT are warranted based on the evidence from acute trials showing milk proteins suppress postprandial glycaemia chronic fasting hyperinsulinaemia and insulin resistance.

\section{Milk proteins and blood lipids \\ Postprandial dyslipidaemia}

Dyslipidaemia is one of the main metabolic risk factors associated with CVD risk [60]. Metabolic syndrome is mainly characterized by elevated levels of TG and low levels of HDL-C [4]. Even in the absence of overt dyslipidaemia in metabolic syndrome, postprandial lipaemia can cause transient impairment in endothelial function and other adverse outcomes [61]. Dairy proteins have potential to suppress postprandial lipaemia due to their insulinotropic effects, as insulin is known to inhibit hormone-sensitive lipase and release of FFA [62]. However, studies on the effects of milk protein ingestion on postprandial lipaemia and chronic dyslipidaemia have produced mixed findings [63-70]. Two studies in healthy normolipaemic young men and women reported that 50 g sodium caseinate suppressed the postprandial response following a $70 \mathrm{~g}$ fat bolus, decreasing diet-derived chylomicrons and FFAs independent of gastric emptying, compared to an oligosaccharide bolus $[64,65]$. In another study of normolipaemic young men and women, however, ingestion of a lower dose of $23 \mathrm{~g}$ casein did not significantly modulate the postprandial lipaemic response to a $40 \mathrm{~g}$ fat meal [63].

In a study of obese post-menopausal women, $45 \mathrm{~g}$ whey protein isolate or sodium caseinate with breakfast both decreased the postprandial appearance of chylomicronderived TG as well as the TG:ApoB48 ratio [66]. There was no change in total cholesterol, LDL-C, HDL-C, FFA 
or ApoB48 alone. Since postprandial effects appear to predominate, it was unsurprising that the cholesterol moieties did not change postprandially. When investigating the effect of different types of dairy proteins, also in obese individuals, a similar bolus of $45 \mathrm{~g}$ whey protein isolate, whey protein hydrolysate, alpha-lactalbumin or casein glycomacropeptide (GMP) did not differentially alter postprandial lipaemia following a fatty meal, although, whey hydrolysate marginally decreased postprandial suppression of FFAs relative to the other dairy fractions [68]. In T2DM patients, $45 \mathrm{~g}$ whey protein has been shown to suppress postprandial TG, FFA and rate of appearance of chylomicronrich lipoproteins after a high-fat meal compared with casein and also non-dairy (cod and gluten) proteins [69], whilst a second study in T2DM patients found no response to $45 \mathrm{~g}$ casein on the postprandial TG response following a similar high-fat meal [67].

As yet the mechanism underpinning the effect of dairy protein on postprandial lipaemia is not well understood. Nevertheless, the evidence of acute effects of dairy protein, particularly whey, on postprandial lipaemia provides a rationale for longer-term supplementation trials to manage dyslipidaemia.

\section{Chronic fasting dyslipidaemia}

There have to date been few long-term randomized trials investigating fasting lipids in healthy individuals or those with adverse metabolic risk. In a study of metabolic syndrome, a significant decrease in fasting TG was demonstrated following a 3 month period of supplementation of $15 \mathrm{~g} /$ day of a fermented whey product, whey malleable protein matrix (MPM, comprising whey proteins, peptides, a probiotic, polysaccharides and calcium) [70], as were other risk factors but only in individuals with high pre-existing metabolic risk. Metabolic outcomes in this study may have been driven by weight loss since body weight also decreased following MPM supplementation. In addition, dairy protein supplementation may provide an indirect way to improve blood lipid profiles when used in conjunction with low fat or low energy diets to induce weight-loss. Certainly there is experimental evidence that whey protein can decrease lipid infiltration into the liver, for example in rodent models of nonalcoholic fatty liver disease (NAFLD) [71], where hepatic TG is normalized through dietary treatment. Dairy protein products appear to have potential to decrease dyslipidaemia in high-risk individuals, but more studies are needed.

\section{Milk proteins, vascular reactivity and blood pressure}

In epidemiological studies, consumption of dairy products including milk and yogurt is associated with decreased risk of hypertension, purported to be driven by a high content of bioactive peptides [20,72]. Whey protein and casein both contain the bioactive peptides lactokinins or caseinkinins respectively. In-vitro experiments indicate these peptides can inhibit ACE activity [25]. $\mathrm{ACE}$ is a rate limiting enzyme in the conversion of angiotensin I to angiotensin II responsible for vasoconstriction. Therefore, lactokinins or caseinkinins both have potential to lower blood pressure. Vascular reactivity is important for glucose disposal and regulation of blood flow, but is impaired in patients with metabolic syndrome due to decreased insulin-stimulated vasodilation via the eNOS pathway and suppressed NO production in the vascular endothelium [73]. In a recent study of older overweight adults with impaired vascular endothelial function, $5 \mathrm{~g}$ of a novel whey protein-derived extract increased brachial artery flow-mediated dilation over a 2 hour period compared to a placebo [74], although notably without inhibition of ACE activity or alteration of circulating endothelium factors including plasma NO, prostacyclin metabolites or endothelin-1 [74]. Evidence for improvements in blood pressure has been steadily growing in the majority [75-80], although not all trials [81]. In a study of overweight postmenopausal women, $45 \mathrm{~g}$ whey protein isolate and sodium caseinate had no effect on postprandial arterial stiffness or on blood pressure over 6 hours [81]. Conversely, in overweight men and women with mild hypertension, 6 weeks of supplementation with $28 \mathrm{~g} /$ day whey protein concentrate or hydrolysate decreased both systolic and diastolic pressure as well as mean arterial pressure [75]. Whilst in a group of pre- and hypertensive individuals, 6 weeks of supplementation with $20 \mathrm{~g} /$ day whey protein hydrolysate was shown to further decrease blood pressure compared to intact whey protein [76], despite no detectable differences in ACE activity. Interestingly, in a longer 12 week trial of overweight, normo- and hypertensive men and women, $54 \mathrm{~g} /$ day whey protein isolate or sodium caseinate were both reported to decrease blood pressure and arterial stiffness compared to a glucose control [77]. Reductions in systolic blood pressure have also been found following supplementation with fermented or immune modified milks [78,79], and clinical trials of whey peptides on blood pressure and vascular function have produced some promising findings [80].

\section{Milk proteins, immune response and inflammation}

A chronic low-grade inflammatory state accompanies obesity, evident from both elevated systemic inflammatory markers in serum and infiltration of inflammatory cells into tissues. In obese humans, serum levels of pro-inflammatory cytokines are elevated and peripheral blood mononuclear cells are activated [82]. Inflammatory cytokines can increase insulin resistance and inhibit glucose uptake in peripheral tissues, as well as increase proteolysis of skeletal muscle cells. Evidence from in-vitro 
studies suggests that dairy proteins and milk derived peptides have immunosuppressive or immunostimulatory effects [29]. Kappa-casein has been reported to suppress lymphocyte proliferation induced by $\mathrm{T}$ and $\mathrm{B}$ cell mitogens [83]. Whey protein and its hydrolysates have been to inhibit the proliferation of lymphocytes, without the induction of apoptosis [84]. When mitogens or antigens activate $\mathrm{T}$ lymphocytes they produce cytokines and upregulate cell surface immune receptors. Whey proteins lactoferrin and lactoperoxidase have been shown to suppress interferon secretion from mitogen activated lymphocytes [85]. Animal studies indicate whey protein and casein or their peptides have immunomodulatory effects in-vivo, but these are not always in concordance with effects observed in-vitro [29]. There have been very few studies on whether whey protein or casein can modulate inflammation and immune response in individuals with impaired metabolic control. A recent study in obese non-diabetic individuals given a high fat mixed meal and whey protein isolate revealed the CCL5 response, an indicator of immune activation, in the $4 \mathrm{~h}$ postprandial period [86]. In addition, the $\mathrm{MCP}-1$ response was higher after the whey protein isolate compared to other proteins [86]. Another recent study in patients undergoing surgery reported that a whey protein and $\mathrm{CHO}$ drink decreased the postoperative acute phase response and insulin resistance [87]. Conversely, in a group of overweight postmenopausal women, a $45 \mathrm{~g}$ whey protein isolate or sodium caseinate bolus did not decrease postprandial plasma inflammatory markers, IL-6, TNF- $\alpha$ or acute phase C-reactive protein (CRP) over a 6 hour period compared to glucose ingestion [81]. Similarly, in a longer term study in overweight and obese individuals, whey protein or casein supplementation for 12 weeks was reported not to influence plasma inflammatory markers [77]. However, in patients with chronic obstructive disease (COPD) undergoing a low-intensity exercise therapy, whey peptide was found to decrease circulating IL-6, IL-8, TNF $\alpha$ and hsCRP, accompanied by an increased exercise tolerance [88]. While in-vitro evidence indicates that whey protein and casein have immunomodulatory effects, more in-vivo studies are required to assess whether these proteins can modulate the immune response in individuals with impaired metabolic health and low-grade inflammation.

\section{Milk proteins and appetite control}

In addition to the direct effects of dairy protein on metabolic health, milk proteins may indirectly drive improvements in metabolic control through the enhancement of the control of appetite and/or other mechanisms which aid changes in both body weight and composition. Highprotein foods have long been shown to have favourable effects on satiety [89-95], and whilst not all studies show suppression of food intake [96-99], altering the diet in favour of a higher protein component may well have a role to play in weight control [100-105]. The significant advantage of a high dairy diet for appetite suppression and weight loss is the anabolic effect of dairy BCAAs on lean body mass. BCAAs enhance muscle protein synthesis and skeletal muscle mass, and may protect against loss of lean mass during periods of weight loss [106]. As the largest organ group in the body and a highly metabolically active tissue, protection of skeletal mass may in turn contribute to an improvement in whole body metabolic health.

Whether different protein types have different effects on food intake however is not as yet well demonstrated, although there are some studies which have shown greater satiety for some dairy proteins relative to soy protein $[107,108]$ or other non-dairy proteins [109]. Interestingly skimmed milk containing both whey protein and casein has been shown to decrease intake more than either protein alone in a study of isoenergetic preloads [110], whilst in another study whey protein in turn has been shown to suppress intake more than casein [38]. Various whey protein-derived fractions may also have differential effects on satiety, including GMP which has long been purported to suppress food intake. Supportive evidence however is lacking [106,107]. In an isoenergetic study of whey protein, whey protein plus GMP, whey protein-derived alpha-lactalbumin ( $\alpha$-lac), casein and non-dairy soy protein, it was $\alpha$-lac that was shown to suppress intake relative to the other fractions [111], whilst in a study comparing various forms of GMP no differential effects on intake were reported [112]. In a recent study of overweight women from our laboratory we also found no differential effect of GMP on energy intake [113] when we gave matched beverages containing $25 \mathrm{~g}$ of whey protein concentrate, GMP, betalactoglobulin ( $\beta$-lac) and colostrum-derived whey protein, although greater fullness was induced by $\beta$-lac [113].

In one of the early studies, protein-induced appetite suppression was attributed to both an altered rate of gastric emptying and an increase in postprandial serum AA concentrations following whey protein consumption [38]. Differential effects have also been attributed to threshold concentrations of total serum AAs in more recent studies of whey protein-induced hunger suppression when whey and casein were given in a mixed preload meal [107]. Interestingly in this study a lower dose (15 g, 10 en\% protein) had a greater effect than a higher dose (38 g, 25 en\% protein) [107]. Despite some differential effects of whey protein fractions in our recent study [113], we were unable to find a relationship between circulating levels of total AAs and measures of either hunger, satiety or food intake. It is possible that tryptophan may be the most important of the AAs for appetite suppression since 5-hydroxytryptophan (5HT, serotonin) is an established appetite-modulating neurotransmitter [107], but 
this remains as yet unsubstantiated. Other postulated mechanisms include regulation of satiety by the gastrointestinal (GI) peptides such as glucagon like peptide-1 (GLP-1), CCK and peptide YY (PYY) [114-116]. Circulating levels of these peptides clearly are altered following a meal where they have a role in digestion, absorption and the metabolic fate of ingested nutrients, but there remains questions around their role in the control of hunger, satiety and eating behavior $[97,117]$. Our review of the literature and that of others [118] leads to the conclusion that the role played by these peptides in the control of food intake is poorly demonstrated. De Graaf et al., [118] observed that peptide concentrations induced through exogenous (pharmaceutical) administration are several-fold greater than those which occur when a meal is consumed [118], Whilst GLP-1 and PYY have clear anorectic effects at high pharmacological levels, following a meal blood concentrations remain relatively low and neither is likely to contribute significantly to the satiating effect of protein or other macronutrients [118]. Circulating CCK levels following a high protein meal are closer to those achieved following exogenous infusion, yet the evidence that CCK is a critical driver in human satiety also remains elusive.

Unsurprisingly, the postprandial effects of dairy protein on GI hormones and energy intake are mixed, with changes in peptide concentrations rarely driving predictable changes in energy intake [118]. For example, in a study of lean and obese men, $50 \mathrm{~g}$ of whey protein resulted in a prolonged postprandial suppression of ghrelin, increased GLP-1 and CCK, and as hypothesized, decreased energy intake of $\sim 10 \%$ [95]. Conversely, a study in obese men reported that $50 \mathrm{~g}$ whey protein resulted in a prolonged suppression of ghrelin, elevation of GLP-1 and CCK [97], but no detectable changes in energy intake [97]. Hence, changes in gut satiety peptides in response to pre-meal protein beverages or after a meal do not reliably translate into changes in subjective appetite and satiety ratings or energy intake.

\section{Milk proteins and body weight}

Weight-loss diets are widely undertaken to lose excess abdominal fat, which has implications for metabolic health since visceral adipose tissue produces inflammatory cytokines, which can inhibit insulin action in skeletal muscle. Recent evidence has highlighted the role that dietary protein may play in weight control [105], with a large scale European Union study, DIOGENES, reporting that long-term weight loss maintenance was obtained most effectively in overweight individuals allowed to eat a high-protein, low glycaemic index (GI) diet [105]. There have been several long-term studies of the effect of dairy protein on body composition both in the presence or absence of a weight-loss or weight-loss maintenance diet, which are reviewed below.

\section{Ad libitum diets for weight-loss}

In a randomized controlled trial, supplementation with $\sim 56 \mathrm{~g} /$ day whey protein concentrate for 6 months without any dietary advice resulted in significantly lower body weight, fat mass and waist circumference in overweight and obese individuals compared to an isoenergetic $\mathrm{CHO}$ control [108]. In a second, shorter trial of overweight and obese individuals with pre-existing metabolic risk however, 54 g/ day of whey protein isolate for 3 months failed to cause weight loss, but notably metabolic health improved through decreased fasting blood lipids and insulin levels [59].

\section{Energy restricted diets for weight-loss}

Whilst an energy-restricted diet provides an effective way to decrease adipose tissue mass and abdominal obesity, energy intake below basal metabolic requirements also leads to skeletal muscle loss. Weight-regain after an energy restricted diet often occurs, in part due to the decrease in basal metabolic rate (BMR) resulting from loss of metabolically active skeletal muscle mass. In middleaged and older obese participants existing muscle sarcopenia may further exacerbate this weight-regain [6]. The effectiveness of whey protein in conjunction with dietary advice to improve adiposity and lean body mass in addition to body weight per se has been assessed in several studies. Whey protein is well established as a driver of skeletal muscle anabolism, with its constituent BCAAs such as leucine driving greater protein synthesis $[119,120]$. As such, a high dairy protein diet may enhance metabolic health through maintenance of lean body mass during weight loss. In a randomized trial of obese individuals on an energy restricted diet, a milk protein based supplement lead to higher fat loss and preservation of lean mass, as well as greater overall weight-loss [121]. Another study in obese men also reported that consumption of a high protein meal replacement containing whey protein, soy protein and AAs resulted in greater adipose loss over 12 weeks compared to a standard protein meal replacement plan [122]. A recent study of overweight elderly has also shown that supplementation with whey protein plus EAAs during an energy restricted diet promoted skeletal muscle protein synthesis compared with standard meal replacements, and in turn promoted greater adipose loss [123]. Unexpectedly in this study however there was no increase in skeletal muscle mass during EAA supplementation. Conversely, a shorter-term study of whey protein supplementation during 8 weeks of weight-reduction followed by 12 weeks weight-maintenance did not alter body weight or composition compared to a $\mathrm{CHO}$ control, although the small sample size of only 18 participants greatly limited the power to detect changes in fat or lean tissue mass and raises questions on the findings of this trial [98]. 
Whether whey protein or casein may be more effective for adipose loss and/or skeletal mass sparing during energy restriction is not known. One recent study in obese individuals on a 6 week energy restricted, weight loss diet with $\sim 60 \mathrm{~g} /$ day casein or whey protein supplementation reported no differences in fat or lean mass changes between the groups [124]. Casein supplementation did however result in greater inhibition of protein degradation despite lower protein synthesis, and an overall greater positive protein balance. Possibly the duration of the study was too short for effects on body composition changes to be detected [124]. In a longer study, in obese individuals with increased metabolic risk, both whey protein and casein supplementation were more effective for maintenance of body weight and adipose-loss over 12 weeks compared to $\mathrm{CHO}$ supplementation, but no differences were found between the whey protein or casein supplemented groups [125]. Taken together, an energy restricted diet combined with whey protein or casein supplementation may help to enhance body weight and adipose loss whilst maintaining skeletal muscle mass essential for good metabolic control. There is however no consensus in support of differential effects of whey protein versus casein for weight-loss or improved body composition.

\section{Milk proteins and maintenance of metabolically active muscle}

Skeletal muscle mass is determined by net balance between the synthesis of new proteins and degradation of existing proteins. In addition, storage of $\mathrm{CHOs}$ in the form of glycogen and lipids in the form of intramyocellular TGs contribute to minor fluctuations in skeletal muscle mass. Daily turnover of skeletal muscle protein in healthy recreationally active humans is around $1-2 \%$ day [126]. Protein synthesis is increased postprandially several times a day and decreased during fasting. The postprandial response appears to be gradually blunted during aging however, and this lower rate of muscle protein synthesis may be a key factor in aging sarcopenia [127]. Exercise is also important, and there is evidence that skeletal muscle turnover in young, sedentary individuals may be lower than active, elderly individuals [128]. Regular dairy protein supplementation in individuals with impaired metabolic control exacerbated by poor muscle mass, often a result of physical inactivity and/or ageing, has been postulated to prevent further loss of lean mass and promote skeletal muscle accretion and enhanced function.

\section{Enhanced muscle mass and function}

Milk proteins provide a potent anabolic stimulus due to their AA composition and insulinotropic effects, although whether whey protein or casein have greater differential effects on muscle mass and/or function is not yet well understood. An early study in the mid 1990s found that postprandial whole body protein synthesis was increased $68 \%$ after ingestion of whey protein but only $31 \%$ after ingestion of casein [40]. However, casein but not whey inhibited whole body protein breakdown and so despite the more rapid appearance of whey-derived AAs, net protein balance was higher following casein ingestion [40]. Similar observations have been made in later studies where the slow digestion of casein or milk protein concentrate resulted in a more sustained appearance of AAs and protein accretion, despite lower peak levels of BCAAs $[41,129]$. There is also temporal variation in protein synthesis rates, with a recent study using intrinsically labeled whey protein and casein co-ingested as milk showing that AA absorption and retention across a lower limb were similar for both whey protein and casein-derived AAs for the first 2 hours, but were higher in casein-derived AAs after $>3$ hours [130]. Conversely in a study of older men [37], $20 \mathrm{~g}$ of whey protein resulted in greater postprandial muscle accretion over 6 hours compared to either casein or casein hydrolysate, despite similar peak rates of serum AA appearance between whey protein and hydrolysed casein. This was attributed to the higher leucine content of whey protein [37], which in combination with its insulinotropic effects may be important to overcome insulin resistance in individuals with poor metabolic control. Whether post-prandially induced increases in protein synthesis by milk proteins is sufficient to result in net skeletal mass accretion over time without exercise is yet to be established. Resistance exercise alone provides an anabolic stimulus, therefore ingestion of milk protein is likely to be more advantageous in combination with exercise interventions to improve metabolic health.

\section{Synergies with exercise}

Progressive exercise training causes multiple physiological adaptations in skeletal muscle, which underpin increased insulin sensitivity, metabolic control and functional changes. These physiological adaptations require synthesis of new proteins and breakdown of existing proteins. After acute resistance or endurance type exercise, protein synthesis and protein breakdown are transiently increased dependent upon both the work load and intensity [126]. Milk protein ingestion in combination with resistance exercise training may result in greater skeletal muscle hypertrophy, and in turn increased insulin sensitivity, metabolic control and BMR. On the same premise milk protein ingestion may be postulated to accelerate the metabolic adaptation to either resistance or endurance type exercise training. The main evidence for this is based on acute increases in whole body or muscle protein synthesis rates after exercise following ingestion of milk proteins. For example, after resistance 
exercise, acute ingestion of $20 \mathrm{~g}$ of both whey protein and casein resulted in an increase in net muscle protein balance [131]. Direct assessment of myofibrillar protein synthesis rate 1-6 $\mathrm{h}$ post exercise revealed similar increases after $20 \mathrm{~g}$ dose of whey protein or casein, although as expected whey produced a marked increase in the early period whereas casein produced a more moderate but prolonged increase [44]. Acute, early phase, post exercise muscle protein synthesis was also higher following whey protein hydrolysate compared to casein [132]. By far the majority of studies of milk protein supplementation on skeletal muscle synthesis have been conducted in young healthy individuals or the elderly. Protein synthesis may be blunted with insulin resistance, therefore whether milk proteins can enhance post-exercise muscle protein synthesis and also longer term exercise-induced metabolic adaptations in obesity, metabolic syndrome or T2DM is of great interest.

Two recent studies in overweight individuals, where chronic exercise training was combined with milk protein supplementation, provide little consensus for increases in muscle mass and metabolic adaptation. In a 6 week randomized controlled trial in overweight young men, $3 \times 30 \mathrm{~g} /$ day whey protein isolate combined with resistance exercise did not result in greater improvement in metabolic risk compared to a placebo of starch [133]. The test supplements were ingested immediately after exercise, and also with lunch and dinner each day. The duration of the intervention was relatively short, given that metabolic adaptations to training, such as increased muscle mass and insulin sensitivity, may take over 12 weeks to occur [134]. In a longer-term 6 month study of weight loss in overweight, older women, $2 \times 25 \mathrm{~g} /$ day whey protein isolate in conjunction with an energy restricted diet and exercise training resulted in both a trend towards greater weight loss, and MRI-assessed adipose loss and gain in leg muscle mass [135]. Perhaps unexpectedly there is as yet limited evidence even in young healthy participants and bodybuilders that protein supplementation in combination with resistance exercise training does lead to greater gains in skeletal muscle mass [136-138], despite the growing literature supporting effects on protein synthesis, degradation and balance. In a study of elderly men undertaking a 12 week progressive resistance type exercise program, the addition of a protein supplement, perhaps surprisingly, did not further increase skeletal muscle hypertrophy and enhance lean body mass [139]. Habitual protein intake may be a factor which influences the potential benefits of dairy supplementation in combination with exercise.

\section{Conclusions}

Epidemiological evidence shows dairy consumption to be associated with a decreased prevalence of metabolic related disorders, supported by experimental studies showing milk protein decreases the prevalence of individual metabolic risk factors such as hypertension, dyslipidaemia, and mild hyperglycaemia. As well as via direct mechanisms, there is also evidence that milk protein may indirectly improve metabolic health by promoting changes in body composition in favour of increased lean body mass and decreased adiposity, particularly during energy-restricted weight loss. BCAAs, present in high levels in milk protein, enhance muscle protein synthesis, lean body mass and skeletal muscle metabolic function. 'Sarcobesity', where the adverse metabolic profile of overweight and obesity is superimposed onto a declining, inadequate and poorly functional skeletal muscle mass, is a rapidly growing health issue, and lifestyle changes which include an energy restricted diet and increased activity can lead to significant improvements in metabolic health. Whey protein supplementation has positive effects on postprandial and post-exercise glucose, lipid and protein metabolism and may prevent declining metabolic health if used in conjunction with lifestyle changes. Large randomized milk protein supplementation trials combined with lifestyle changes are still required however to generate robust evidence supporting the use of milk protein products to improve or manage metabolic health.

\section{Competing interests}

SDP holds the Fonterra Chair in Human Nutrition at the University of Auckland. RAM receives financial support from the New Zealand Primary Growth Partnership (PGP) program, funded by Fonterra Co-operative group and the NZ Ministry for Primary Industries (MPI).

\section{Authors' contributions}

RAM and SDP wrote the manuscript and are responsible for all content. Both authors read and approved the final manuscript.

\section{Acknowledgements}

Angela Rowan, Fonterra Research and Development Centre, is acknowledged for comments on the manuscript.

\section{Author details}

${ }^{1}$ School of Biological Sciences, University of Auckland, Auckland 1010, New Zealand. 'University of Auckland Human Nutrition Unit, 18 Carrick Place, Mt Eden, Auckland 1024, New Zealand. ${ }^{3}$ Department of Medicine, University of Auckland, Auckland 1010, New Zealand. ${ }^{4}$ Riddet Institute, Palmerston North 4442, New Zealand.

Received: 25 March 2013 Accepted: 23 June 2013

Published: 3 July 2013

\section{References}

1. Gu D, Reynolds K, Wu X, Chen J, Duan X, Reynolds RF, et al: Prevalence of the metabolic syndrome and overweight among adults in China. Lancet 2005, 365(9468):1398-1405.

2. Ford ES, Li C, Zhao G: Prevalence and correlates of metabolic syndrome based on a harmonious definition among adults in the US. J Diabetes 2010, 2(3):180-193.

3. Alberti KGMM, Eckel RH, Grundy SM, Zimmet PZ, Cleeman JI, Donato KA, et al: Harmonizing the metabolic syndrome: a joint interim statement of the International Diabetes Federation Task Force on Epidemiology and Prevention; National Heart, Lung, and Blood Institute; American Heart Association; World Heart Federation; International Atherosclerosis Society; and International Association for the Study of Obesity. Circulation 2009, 120(16):1640-1645. 
4. Grundy SM, Cleeman JI, Daniels SR, Donato KA, Eckel RH, Franklin BA, et al: Diagnosis and management of the metabolic syndrome: an American Heart Association/National Heart, Lung, and Blood Institute Scientific Statement. Circulation 2005, 112(17):2735-2752.

5. Eckel RH, Grundy SM, Zimmet PZ: The metabolic syndrome. Lancet 2005, 365(9468):1415-1428.

6. Parr EB, Coffey VG, Hawley JA: "Sarcobesity": a metabolic conundrum. Maturitas 2013, 74:109-113.

7. Kwon E-Y, Shin S-K, Cho Y-Y, Jung UJ, Kim E, Park T, et al: Time-course microarrays reveal early activation of the immune transcriptome and adipokine dysregulation leads to fibrosis in visceral adipose depots during diet-induced obesity. BMC Genomics 2012, 13(1):450

8. Cornier M-A, Dabelea D, Hernandez TL, Lindstrom RC, Steig AJ, Stob NR, et al: The metabolic syndrome. Endocr Rev 2008, 29(7):777-822.

9. Nazare J-A, Smith JD, Borel A-L, Haffner SM, Balkau B, Ross R, et al: Ethnic influences on the relations between abdominal subcutaneous and visceral adiposity, liver fat, and cardiometabolic risk profile: the International study of prediction of intra-abdominal adiposity and its relationship with cardiometabolic risk/intra-abdominal adiposity. Am J Clin Nutr 2012, 96(4):714-726.

10. Hotamisligil GS: Inflammation and metabolic disorders. Nature 2006, 444(7121):860-867.

11. Nicklas BJ, Wang X, You T, Lyles MF, Demons J, Easter L, et al: Effect of exercise intensity on abdominal fat loss during calorie restriction in overweight and obese postmenopausal women: a randomized, controlled trial. Am J Clin Nutr 2009, 89(4):1043-1052.

12. Campbell WW, Haub MD, Wolfe RR, Ferrando AA, Sullivan DH, Apolzan JW, et al: Resistance training preserves fat-free mass without impacting changes in protein metabolism after weight loss in older women. Obesity (Silver Spring) 2009, 17(7):1332-1339.

13. Foster-Schubert KE, Alfano CM, Duggan CR, Xiao L, Campbell KL, Kong A, et al: Effect of diet and exercise, alone or combined, on weight and body composition in overweight-to-obese postmenopausal women. Obesity (Silver Spring) 2012, 20(8):1628-1638.

14. Kelley DE, Goodpaster B, Wing RR, Simoneau JA: Skeletal muscle fatty acid metabolism in association with insulin resistance, obesity, and weight loss. Am J Physiol 1999, 277(6 Pt 1):E1130-E1141.

15. Chung J-Y, Kang H-T, Lee D-C, Lee H-R, Lee $Y$-J: Body composition and its association with cardiometabolic risk factors in the elderly: a focus on sarcopenic obesity. Arch Gerontol Geriatr 2013, 56(1):270-278.

16. Malenfant $P$, Tremblay $A$, Doucet $E$, Imbeault $P$, Simoneau JA, Joanisse DR: Elevated intramyocellular lipid concentration in obese subjects is not reduced after diet and exercise training. Am J Physiol Endocrinol Metab 2001, 280(4):E632-E639.

17. Chevalier S, Marliss EB, Morais JA, Lamarche M, Gougeon R: Whole-body protein anabolic response is resistant to the action of insulin in obese women. Am J Clin Nutr 2005, 82(2):355-365.

18. Rennie MJ: Anabolic resistance: the effects of aging, sexual dimorphism, and immobilization on human muscle protein turnover. Appl Physiol Nutr Metab 2009, 34(3):377-381.

19. Pal S, Radavelli-Bagatini S: The effects of whey protein on cardiometabolic risk factors. Obes Rev 2012. doi:10.1111/obr.12005.

20. Rice BH, Cifelli CJ, Pikosky MA, Miller GD: Dairy components and risk factors for cardiometabolic syndrome: recent evidence and opportunities for future research. Adv Nutr 2011, 2(5):396-407.

21. Sousa GTD, Lira FS, Rosa JC, De Oliveira EP, Oyama LM, Santos RV, et al: Dietary whey protein lessens several risk factors for metabolic diseases: a review. Lipids Health Dis 2012, 11:67.

22. Jakubowicz D, Froy O: Biochemical and metabolic mechanisms by which dietary whey protein may combat obesity and Type 2 diabetes. J Nutr Biochem 2013, 24(1):1-5.

23. Graf S, Egert $\mathrm{S}$, Heer M: Effects of whey protein supplements on metabolism: evidence from human intervention studies. Curr Opin Clin Nutr Metab Care 2011, 14(6):569-580.

24. Crichton GE, Bryan J, Buckley J, Murphy KJ: Dairy consumption and metabolic syndrome: a systematic review of findings and methodological issues. Obes Rev 2011, 12(5):e190-e201.

25. Ricci-Cabello I, Herrera MO, Artacho R: Possible role of milk-derived bioactive peptides in the treatment and prevention of metabolic syndrome. Nutr Rev 2012, 70(4):241-255.
26. Esteves De Oliveira FC, Pinheiro Volp AC, Alfenas RC: Impact of different protein sources in the glycemic and insulinemic responses. Nutr Hosp 2011, 26(4):669-676.

27. Westerterp-Plantenga MS, Nieuwenhuizen A, Tomé D, Soenen S, Westerterp KR: Dietary protein, weight loss, and weight maintenance. Annu Rev Nutr 2009, 29(1):21-41.

28. Saito T: Antihypertensive peptides derived from bovine casein and whey proteins. Adv Exp Med Biol 2008, 606:295-317.

29. Cross ML, Gill HS: Immunomodulatory properties of milk. Br J Nutr 2000, 84(S1):81-89.

30. Fumeron F, Lamri A, Abi Khalil C, Jaziri R, Porchay-Baldérelli I, Lantieri O, et al: Dairy consumption and the incidence of hyperglycemia and the metabolic syndrome: results from a french prospective study, Data from the Epidemiological Study on the Insulin Resistance Syndrome (DESIR). Diabetes Care 2011, 34(4):813-817

31. Beydoun MA, Gary TL, Caballero BH, Lawrence RS, Cheskin LJ, Wang Y: Ethnic differences in dairy and related nutrient consumption among US adults and their association with obesity, central obesity, and the metabolic syndrome. Am J Clin Nutr 2008, 87(6):1914-1925.

32. Morr CV, Ha EY: Whey protein concentrates and isolates: processing and functional properties. Crit Rev Food Sci Nutr 1993, 33(6):431-476.

33. Dalgleish DG, Corredig M: The structure of the casein micelle of milk and its changes during processing. Annu Rev Food Sci Technol 2012, 3:449-467.

34. Huffman LM, Harper WJ: Maximizing the value of milk through separation technologies. J Dairy Sci 1999, 82(10):2238-2244.

35. Boye J, Wijesinha-Bettoni R, Burlingame B: Protein quality evaluation twenty years after the introduction of the protein digestibility corrected amino acid score method. Br J Nutr 2012, 108:S183-S211.

36. FAO United Nations Expert Consultation (Ed): Dietary protein quality evaluation in human nutrition. Auckland; 2011

37. Pennings B, Boirie $Y$, Senden JM, Gijsen AP, Kuipers $H$, Van Loon L: Whey protein stimulates postprandial muscle protein accretion more effectively than do casein and casein hydrolysate in older men. Am J Clin Nutr 2011, 93(5):997-1005.

38. Hall WL, Millward DJ, Long SJ, Morgan LM: Casein and whey exert different effects on plasma amino acid profiles, gastrointestinal hormone secretion and appetite. Br J Nutr 2003, 89(2):239-248.

39. Bassil MS, Gougeon R: Muscle protein anabolism in type 2 diabetes. Curr Opin Clin Nutr Metab Care 2013, 16(1):83-88.

40. Boirie $Y$, Dangin M, Gachon P, Vasson MP, Maubois JL, Beaufrère B: Slow and fast dietary proteins differently modulate postprandial protein accretion. Proc Natl Acad Sci USA 1997, 94(26):14930-14935.

41. Dangin M, Boirie Y, Garcia-Rodenas C, Gachon P, Fauquant J, Callier P, et al: The digestion rate of protein is an independent regulating factor of postprandial protein retention. Am J Physiol Endocrinol Metab 2001, 280(2):E340-E348.

42. Calbet JAL, Holst JJ: Gastric emptying, gastric secretion and enterogastrone response after administration of milk proteins or their peptide hydrolysates in humans. Eur J Nutr 2004, 43(3):127-139.

43. Claessens M, Saris WHM, Van Baak MA: Glucagon and insulin responses after ingestion of different amounts of intact and hydrolysed proteins. Br J Nutr 2008, 100(1):61-69.

44. Reitelseder S, Agergaard J, Doessing S, Helmark IC, Lund P, Kristensen NB, et al: Whey and casein labeled with I-[1-13C]leucine and muscle protein synthesis: effect of resistance exercise and protein ingestion. Am J Physiol Endocrinol Metab 2011, 300(1):E231-E242.

45. Nilsson M, Stenberg M, Frid AH, Holst JJ, Björck IME: Glycemia and insulinemia in healthy subjects after lactose-equivalent meals of milk and other food proteins: the role of plasma amino acids and incretins. Am J Clin Nutr 2004, 80(5):1246-1253.

46. Nilsson M, Holst JJ, Björck IM: Metabolic effects of amino acid mixtures and whey protein in healthy subjects: studies using glucose-equivalent drinks. Am J Clin Nutr 2007, 85(4):996-1004.

47. Pistrosch F, Natali A, Hanefeld M: Is Hyperglycemia a cardiovascular risk factor? Diabetes Care 2011, 34(S2):S128-S131.

48. Gerich JE: CLinical significance, pathogenesis, and management of postprandial hyperglycemia. Arch Intern Med 2003, 163(11):1306-1316.

49. Akhavan T, Luhovyy BL, Brown PH, Cho CE, Anderson GH: Effect of premeal consumption of whey protein and its hydrolysate on food intake and postmeal glycemia and insulin responses in young adults. Am J Clin Nutr 2010, 91(4):966-975. 
50. Claessens M, Calame W, Siemensma AD, Van Baak MA, Saris WHM: The effect of different protein hydrolysate/carbohydrate mixtures on postprandial glucagon and insulin responses in healthy subjects. Eur J Clin Nutr 2009, 63(1):48-56.

51. Pal S, Ellis V: The acute effects of four protein meals on insulin, glucose, appetite and energy intake in lean men. Br J Nutr 2010, 104(8):1241-1248.

52. Gunnerud UJ, Heinzle C, Holst JJ, Ostman EM, Björck IME: Effects of premeal drinks with protein and amino acids on glycemic and metabolic responses at a subsequent composite meal. PLoS One 2012, 7(9):e44731.

53. Frid AH, Nilsson M, Holst JJ, Björck IME: Effect of whey on blood glucose and insulin responses to composite breakfast and lunch meals in type 2 diabetic subjects. Am J Clin Nutr 2005, 82(1):69-75.

54. Ma J, Stevens JE, Cukier K, Maddox AF, Wishart JM, Jones KL, et al: Effects of a protein preload on gastric emptying, glycemia, and gut hormones after a carbohydrate meal in diet-controlled type 2 diabetes. Diabetes Care 2009, 32(9):1600-1602.

55. Moller DE: New drug targets for type 2 diabetes and the metabolic syndrome. Nature 2001, 414(6865):821-827.

56. Manders RJF, Praet SFE, Meex RCR, Koopman R, De Roos AL, Wagenmakers $\mathrm{AJM}$, et al: Protein hydrolysate/leucine co-ingestion reduces the prevalence of hyperglycemia in type 2 diabetic patients. Diabetes Care 2006, 29(12):2721-2722.

57. Manders RJF, Praet SFE, Vikström MH, Saris WHM, Van Loon LC: Protein hydrolysate co-ingestion does not modulate $24 \mathrm{~h}$ glycemic control in long-standing type 2 diabetes patients. Eur J Clin Nutr 2009, 63(1):121-126.

58. Van Loon LJC, Kruijshoop M, Menheere PPCA, Wagenmakers AJM, Saris WHM, Keizer HA: Amino acid ingestion strongly enhances insulin secretion in patients with long-term type 2 diabetes. Diabetes Care 2003, 26(3):625-630.

59. Pal $\mathrm{S}$, Ellis V, Dhaliwal $\mathrm{S}$ : Effects of whey protein isolate on body composition, lipids, insulin and glucose in overweight and obese individuals. Br J Nutr 2010, 104(5):716-723.

60. Ginsberg HN, Zhang Y-L, Hernandez-Ono A: Metabolic syndrome: focus on dyslipidemia. Obesity 2006, 14(S2):41S-49S.

61. Jackson KG, Poppitt SD, Minihane AM: Postprandial lipemia and cardiovascular disease risk: Interrelationships between dietary, physiological and genetic determinants. Atherosclerosis 2012, 220(1):22-33.

62. Holm C: Molecular mechanisms regulating hormone-sensitive lipase and lipolysis. Biochem Soc Trans 2003, 31(Pt 6):1120-1124.

63. Cohen JC: Protein ingestion does not affect postprandial lipaemia or chylomicron-triglyceride clearance. Eur J Clin Nutr 1989, 43(7):497-499.

64. Westphal S, Kästner S, Taneva E, Leodolter A, Dierkes J, Luley C: Postprandial lipid and carbohydrate responses after the ingestion of a casein-enriched mixed meal. Am J Clin Nutr 2004, 80(2):284-290.

65. Westphal S, Taneva E, Kästner S, Martens-Lobenhoffer J, Bode-Böger S, Kropf $\mathrm{S}$, et al: Endothelial dysfunction induced by postprandial lipemia is neutralized by addition of proteins to the fatty meal. Atherosclerosis 2006, 185(2):313-319.

66. Pal $\mathrm{S}$, Ellis $\mathrm{V}, \mathrm{Ho}$ S: Acute effects of whey protein isolate on cardiovascular risk factors in overweight, post-menopausal women. Atherosclerosis 2010, 212(1):339-344.

67. Brader L, Holm L, Mortensen L, Thomsen C, Astrup A, Holst JJ, et al: Acute effects of casein on postprandial lipemia and incretin responses in type 2 diabetic subjects. Nutr Metab Cardiovasc Dis 2010, 20(2):101-109.

68. Holmer-Jensen J, Hartvigsen ML, Mortensen LS, Astrup A, De Vrese M, Holst $\mathrm{JJ}$, et al: Acute differential effects of milk-derived dietary proteins on postprandial lipaemia in obese non-diabetic subjects. Eur J Clin Nutr 2012, 66(1):32-38

69. Mortensen LS, Hartvigsen ML, Brader LJ, Astrup A, Schrezenmeir J, Holst JJ, et al: Differential effects of protein quality on postprandial lipemia in response to a fat-rich meal in type 2 diabetes: comparison of whey, casein, gluten, and cod protein. Am J Clin Nutr 2009, 90(1):41-48.

70. Gouni-Berthold I, Schulte DM, Krone W, Lapointe J-F, Lemieux P, Predel H-G, et al: The whey fermentation product malleable protein matrix decreases TAG concentrations in patients with the metabolic syndrome: a randomised placebo-controlled trial. Br J Nutr 2012, 107(11):1694-1706.

71. Hamad EM, Taha SH, Abou Dawood A-Gl, Sitohy MZ, Abdel-Hamid M: Protective effect of whey proteins against nonalcoholic fatty liver in rats. Lipids Health Dis 2011, 10:57.
72. Kris-Etherton PM, Grieger JA, Hilpert KF, West SG: Milk products, dietary patterns and blood pressure management. J Am Coll Nutr 2009, 28(S1):103S-119S.

73. Schinzari F, Tesauro M, Rovella V, Galli A, Mores N, Porzio O, et al: Generalized impairment of vasodilator reactivity during hyperinsulinemia in patients with obesity-related metabolic syndrome. Am J Physiol Endocrinol Metab 2010, 299(6):E947-E952.

74. Ballard KD, Kupchak BR, Volk BM, Mah E, Shkreta A, Liptak C, et al: Acute effects of ingestion of a novel whey-derived extract on vascular endothelial function in overweight, middle-aged men and women. Br J Nutr 2012, 13:1-12.

75. Fluegel SM, Shultz TD, Powers JR, Clark S, Barbosa-Leiker C, Wright BR, et al: Whey beverages decrease blood pressure in prehypertensive and hypertensive young men and women. Int Dairy J 2010, 20(11):753-760.

76. Pins JJ, Keenan JM: Effects of whey peptides on cardiovascular disease risk factors. J Clin Hypertens (Greenwich) 2006, 8(11):775-782.

77. Pal $\mathrm{S}$, Ellis $\mathrm{V}$ : The chronic effects of whey proteins on blood pressure, vascular function, and inflammatory markers in overweight individuals. Obesity (Silver Spring) 2010, 18(7):1354-1359.

78. Sharpe SJ, Gamble GD, Sharpe DN: Cholesterol-lowering and blood pressure effects of immune milk. Am J Clin Nutr 1994, 59(4):929-934.

79. Kawase M, Hashimoto H, Hosoda M, Morita H, Hosono A: Effect of administration of fermented milk containing whey protein concentrate to rats and healthy men on serum lipids and blood pressure. J Dairy SC 2000, 83(2):255-263.

80. $\quad$ X J J-Y, Qin L-Q, Wang P-Y, Li W, Chang C: Effect of milk tripeptides on blood pressure: A meta-analysis of randomized controlled trials. Nutrition 2008, 24(10):933-940.

81. Pal S, Ellis V: Acute effects of whey protein isolate on blood pressure, vascular function and inflammatory markers in overweight postmenopausal women. Br J Nutr 2011, 105(10):1512-1519.

82. Ghanim H, Aljada A, Hofmeyer D, Syed T, Mohanty P, Dandona P: Circulating mononuclear cells in the obese are in a proinflammatory state. Circulation 2004, 110(12):1564-1571.

83. Otani $\mathrm{H}$, Hata I: Inhibition of proliferative responses of mouse spleen lymphocytes and rabbit Peyer's patch cells by bovine milk caseins and their digests. J Dairy Res 1995, 62(2):339-348.

84. Eriksen EK, Vegarud GE, Langsrud T, Almaas H, Lea T: Effect of milk proteins and their hydrolysates on in vitro immune responses. Small Rumin Res 2008, 79(1):29-37.

85. Wong CW, Seow HF, Husband AJ, Regester GO, Watson DL: Effects of purified bovine whey factors on cellular immune functions in ruminants. Vet Immunol Immunopathol 1997, 56(1-2):85-96.

86. Holmer-Jensen J, Karhu T, Mortensen LS, Pedersen SB, Herzig K-H Hermansen K: Differential effects of dietary protein sources on postprandial low-grade inflammation after a single high fat meal in obese non-diabetic subjects. Nutr J 2011, 10:115.

87. Perrone F, Da-Silva-Filho AC, Adôrno IF, Anabuki NT, Leal FS, Colombo T, et al: Effects of preoperative feeding with a whey protein plus carbohydrate drink on the acute phase response and insulin resistance. A randomized trial. Nutr J 2011, 10:66.

88. Sugawara K, Takahashi H, Kashiwagura T, Yamada K, Yanagida S, Homma M, et al: Effect of anti-inflammatory supplementation with whey peptide and exercise therapy in patients with COPD. Respir Med 2012, 106 (11):1526-1534.

89. Barkeling B, Rössner S, Björvell H: Effects of a high-protein meal (meat) and a high-carbohydrate meal (vegetarian) on satiety measured by automated computerized monitoring of subsequent food intake, motivation to eat and food preferences. Int J Obes 1990, 14(9):743-751.

90. Porrini M, Crovetti R, Testolin G, Silva S: Evaluation of satiety sensations and food intake after different preloads. Appetite 1995, 25(1):17-30.

91. Poppitt SD, McCormack D, Buffenstein R: Short-term effects of macronutrient preloads on appetite and energy intake in lean women. Physiol Behav 1998, 64(3):279-285.

92. Anderson GH, Moore SE: Dietary proteins in the regulation of food intake and body weight in humans. J Nutr 2004, 134(4):974S-979S.

93. Halton TL, Hu FB: The effects of high protein diets on thermogenesis, satiety and weight loss: a critical review. J Am Coll Nutr 2004, 23(5):373-385.

94. Weigle DS, Breen PA, Matthys CC, Callahan HS, Meeuws KE, Burden VR, et al: A high-protein diet induces sustained reductions in appetite, ad libitum caloric intake, and body weight despite compensatory changes in diurnal plasma leptin and ghrelin concentrations. Am J Clin Nutr 2005, 82(1):41-48 
95. Bowen J, Noakes M, Clifton PM: Appetite regulatory hormone responses to various dietary proteins differ by body mass index status despite similar reductions in ad libitum energy intake. J Clin Endocrinol Metab 2006, 91(8):2913-2919.

96. Blom WAM, Lluch A, Stafleu A, Vinoy S, Holst JJ, Schaafsma G, et al: Effect of a high-protein breakfast on the postprandial ghrelin response. Am J Clin Nutr 2006, 83(2):211-220.

97. Bowen J, Noakes M, Clifton PM: Appetite hormones and energy intake in obese men after consumption of fructose, glucose and whey protein beverages. Int J Obes (Lond) 2007, 31(11):1696-1703.

98. Aldrich ND, Reicks MM, Sibley SD, Redmon JB, Thomas W, Raatz SK: Varying protein source and quantity do not significantly improve weight loss, fat loss, or satiety in reduced energy diets among midlife adults. Nutr Res 2011, 31(2):104-112.

99. Penhoat A, Mutel E, Amigo-Correig M, Pillot B, Stefanutti A, Rajas F, et al: Protein-induced satiety is abolished in the absence of intestinal gluconeogenesis. Physiol Behav 2011, 105(1):89-93

100. Clifton PM, Keogh JB, Noakes M: Long-term effects of a high-protein weight-loss diet. Am J Clin Nutr 2008, 87(1):23-29.

101. Kushner RF, Doerfler B: Low-carbohydrate, high-protein diets revisited. Curr Opin Gastroenterol 2008, 24(2):198-203.

102. Noakes M: The role of protein in weight management. Asia Pac J Clin Nutr 2008, 17(Suppl 1):169-171.

103. Paddon-Jones D, Westman E, Mattes RD, Wolfe RR, Astrup A, WesterterpPlantenga M: Protein, weight management, and satiety. Am J Clin Nutr 2008, 87(5):1558S-1561S.

104. Gilbert J-A, Bendsen NT, Tremblay A, Astrup A: Effect of proteins from different sources on body composition. Nutr Metab Cardiovasc Dis 2011, 21(Suppl 2):B16-B31.

105. Larsen TM, Dalskov S-M, Van Baak M, Jebb SA, Papadaki A, Pfeiffer AFH, et al: Diets with high or low protein content and glycemic index for weight-loss maintenance. N Engl J Med 2010, 363(22):2102-2113.

106. Josse AR, Atkinson SA, Tarnopolsky MA, Phillips SM: Increased consumption of dairy foods and protein during diet- and exercise-induced weight loss promotes fat mass loss and lean mass gain in overweight and obese premenopausal women. J Nutr 2011, 141(9):1626-1634.

107. Veldhorst MAB, Nieuwenhuizen AG, Hochstenbach-Waelen A, Van Vught AJAH, Westerterp KR, Engelen MPK, et al: Dose-dependent satiating effect of whey relative to casein or soy. Physiol Behav 2009, 96(4-5):675-682.

108. Baer DJ, Stote KS, Paul DR, Harris GK, Rumpler W, Clevidence BA: Whey protein but not soy protein supplementation alters body weight and composition in free-living overweight and obese adults. J Nutr 2011, 141(8):1489-1494.

109. Anderson GH, Tecimer SN, Shah D, Zafar TA: Protein source, quantity, and time of consumption determine the effect of proteins on short-term food intake in young men. J Nutr 2004, 134(11):3011-3015.

110. Lorenzen J, Frederiksen R, Hoppe C, Hvid R, Astrup A: The effect of milk proteins on appetite regulation and diet-induced thermogenesis. Eur J Clin Nutr 2012, 66(5):622-627.

111. Veldhorst MAB, Nieuwenhuizen AG, Hochstenbach-Waelen A, Westerterp KR, Engelen MPKJ, Brummer R-JM, et al: A breakfast with alphalactalbumin, gelatin, or gelatin + TRP lowers energy intake at lunch compared with a breakfast with casein, soy, whey, or whey-GMP. Clin Nutr 2009, 28(2):147-155.

112. Keogh JB, Woonton BW, Taylor CM, Janakievski F, Desilva K, Clifton PM: Effect of glycomacropeptide fractions on cholecystokinin and food intake. Br J Nutr 2010, 104(2):286-290.

113. Poppitt S, Strik C, McArdle B, McGill A, Hall R: Evidence of enhanced serum amino acid profile but not appetite suppression by dietary glycomacropeptide (GMP): a comparison of dairy whey proteins. $J$ Am Coll Nutr. in press.

114. De Graaf C, Blom WAM, Smeets PAM, Stafleu A, Hendriks HFJ: Biomarkers of satiation and satiety. Am J Clin Nutr 2004, 79(6):946-961.

115. Karhunen $L J$, Juvonen KR, Huotari A, Purhonen AK, Herzig KH: Effect of protein, fat, carbohydrate and fibre on gastrointestinal peptide release in humans. Regul Pept 2008, 149(1-3):70-78.

116. Fromentin G, Darcel N, Chaumontet C, Marsset-Baglieri A, Nadkarni N, Tomé D: Peripheral and central mechanisms involved in the control of food intake by dietary amino acids and proteins. Nutr Res Rev 2012, 25(1):29-39.

117. Veldhorst MAB, Nieuwenhuizen AG, Hochstenbach-Waelen A, Westerterp KR, Engelen MPKJ, Brummer R-JM, et al: Effects of complete whey-protein breakfasts versus whey without GMP-breakfasts on energy intake and satiety. Appetite 2009, 52(2):388-395.

118. Mars M, Stafleu A, De Graaf C: Use of satiety peptides in assessing the satiating capacity of foods. Physiol Behav 2012, 105(2):483-488.

119. Phillips SM, Tang JE, Moore DR: The role of milk- and soy-based protein in support of muscle protein synthesis and muscle protein accretion in young and elderly persons. J Am Coll Nutr 2009, 28(4):343-354.

120. Van Loon LC: Leucine as a pharmaconutrient in health and disease. Curr Opin Clin Nutr Metab Care 2012, 15(1):71-77.

121. Frestedt J, Zenk J, Kuskowski M, Ward L, Bastian E: A whey-protein supplement increases fat loss and spares lean muscle in obese subjects: a randomized human clinical study. Nutr Metab (Lond) 2008, 5(1):8

122. Treyzon L, Chen S, Hong K, Yan E, Carpenter CL, Thames G, et al: A controlled trial of protein enrichment of meal replacements for weight reduction with retention of lean body mass. Nutr J 2008, 7:23.

123. Coker RH, Miller S, Schutzler S, Deutz N, Wolfe RR: Whey protein and essential amino acids promote the reduction of adipose tissue and increased muscle protein synthesis during caloric restriction-induced weight loss in elderly, obese individuals. Nutr J 2012, 11:105.

124. Adechian S, Balage M, Remond D, Migné C, Quignard-Boulangé A, Marset-Baglieri A, et al: Protein feeding pattern, casein feeding, or milk-soluble protein feeding did not change the evolution of body composition during a short-term weight loss program. Am J Physiol Endocrinol Metab 2012, 303(8):E973-E982.

125. Claessens M, Van Baak MA, Monsheimer S, Saris WHM: The effect of a low-fat, high-protein or high-carbohydrate ad libitum diet on weight loss maintenance and metabolic risk factors. Int J Obes (Lond) 2009, 33(3):296-304

126. Atherton PJ, Smith K: Muscle protein synthesis in response to nutrition and exercise. J Physiol 2012, 590(5):1049-1057.

127. Volpi $E$, Mittendorfer B, Rasmussen BB, Wolfe RR: The response of muscle protein anabolism to combined hyperaminoacidemia and glucose-induced hyperinsulinemia is impaired in the elderly. J Clin Endocrinol Metab 2000, 85(12):4481-4490.

128. Robinson MM, Turner SM, Hellerstein MK, Hamilton KL, Miller BF: Long-term synthesis rates of skeletal muscle DNA and protein are higher during aerobic training in older humans than in sedentary young subjects but are not altered by protein supplementation. FASEB J 2011, 25(9):3240-3249.

129. Lacroix M, Bos C, Léonil J, Airinei G, Luengo C, Daré S, et al: Compared with casein or total milk protein, digestion of milk soluble proteins is too rapid to sustain the anabolic postprandial amino acid requirement. Am J Clin Nutr 2006, 84(5):1070-1079.

130. Soop M, Nehra V, Henderson GC, Boirie Y, Ford GC, Nair KS: Coingestion of whey protein and casein in a mixed meal: demonstration of a more sustained anabolic effect of casein. Am J Physiol Endocrinol Metab 2012, 303(1):E152-E162.

131. Tipton KD, Elliott TA, Cree MG, Wolf SE, Sanford AP, Wolfe RR: Ingestion of casein and whey proteins result in muscle anabolism after resistance exercise. Med Sci Sports Exerc 2004, 36(12):2073-2081.

132. Tang JE, Moore DR, Kujbida GW, Tarnopolsky MA, Phillips SM: Ingestion of whey hydrolysate, casein, or soy protein isolate: effects on mixed muscle protein synthesis at rest and following resistance exercise in young men. J Appl Physiol 2009, 107(3):987-992.

133. Sheikholeslami Vatani D, Ahmadi Kani Golzar F: Changes in antioxidant status and cardiovascular risk factors of overweight young men after six weeks supplementation of whey protein isolate and resistance training. Appetite 2012, 59(3):673-678.

134. Hawley JA, Burke LM, Phillips SM, Spriet LL: Nutritional modulation of training-induced skeletal muscle adaptations. J App/ Physio/ 2011, 110(3):834-845.

135. Mojtahedi MC, Thorpe MP, Karampinos DC, Johnson CL, Layman DK Georgiadis JG, et al: The effects of a higher protein intake during energy restriction on changes in body composition and physical function in older women. J Gerontol A Biol Sci Med Sci 2011, 66(11):1218-1225.

136. Cribb PJ, Williams AD, Carey MF, Hayes A: The effect of whey isolate and resistance training on strength, body composition, and plasma glutamine. Int J Sport Nutr Exerc Metab 2006, 16(5):494-509.

137. Candow DG, Burke NC, Smith-Palmer T, Burke DG: Effect of whey and soy protein supplementation combined with resistance training in young adults. Int J Sport Nutr Exerc Metab 2006, 16(3):233-244. 
138. Cermak NM, De Groot LC, Van Loon LJC: Perspective: protein supplementation during prolonged resistance type exercise training augments skeletal muscle mass and strength gains. J Am Med Dir Assoc 2013, 14(1):71-72.

139. Verdijk LB, Jonkers RAM, Gleeson BG, Beelen M, Meijer K, Savelberg HHCM, et al: Protein supplementation before and after exercise does not further augment skeletal muscle hypertrophy after resistance training in elderly men. Am J Clin Nutr 2009, 89(2):608-616.

doi:10.1186/1743-7075-10-46

Cite this article as: McGregor and Poppitt: Milk protein for improved metabolic health: a review of the evidence. Nutrition \& Metabolism 2013 10:46.

\section{Submit your next manuscript to BioMed Central and take full advantage of:}

- Convenient online submission

- Thorough peer review

- No space constraints or color figure charges

- Immediate publication on acceptance

- Inclusion in PubMed, CAS, Scopus and Google Scholar

- Research which is freely available for redistribution 